DOI 10.32370/2018_11_3

\title{
Location of Industry
}

\author{
Dr. Umar Lawal Aliyu \\ Faculty of Management, Department of Business Administration \\ LIGS University Hawaii, USA \\ lawalacademy@gmail.com
}

\begin{abstract}
The term industry does not only refer to manufacture but all forms of goods and services produced. An industry is the production of goods or related services within an economy. In fact, it is an economic activity concerned with the processing of raw materials and manufacture of goods in factories and the services, which surround the use of these goods. The industry is the greatest sector that can provide employment to the mass people, which help to increase per capita, and reduces the poverty. The economic development of a nation depends on the stage of industrial development. Location of industry is the geographical spread of economic activity within an economy. However, multitude of factors influence the location decisions of firms and industries, including proximity to raw material supplies, availability of labour, good communications and nearness to markets. The placement and expansion of all Government all over the world irrespective of its economic and political policies are all Governments primary concerns. The research work will give definition, types of Industries and Factors of industrial Location. The thesis will tend to analyse location theories, advantage, and disadvantages of industrial location. It is good to note that whether used internally or exported produce from industrial activities generates revenue.
\end{abstract}

Keywords: Economy, Goods, Industry, Location, Manufacturing, Market, Production, Revenue, Services.

\subsection{INTRODUCTION}

Industry is the production of goods or related services within an economy. The major source of revenue of a group or company is the indicator of its relevant industry. The location of industry depends on which type of factory you are going to setup. For example, if you want to set an iron or steel company, you need to setup in place where there are rich iron ores and the waste can be released easily. A good example of this is Ajakuta Steel Rolling mill in Ajakuta in Nigeria by the Federal Government of Nigeria. It was located in Ajakuta in Nigeria were it is rich in Iron ore. Thus, if the industry is related to agriculture you need to setup near village area with fertile land for farming and rearing or breeding of animals. Another good example of this is the Mambila Agricultural production on the Mambilla fertile lands by the Federal Government of Nigeria with capacity area to 850 hectares and an out-grower scheme of 450 hectares. Another example is the Federal Executive Council on recent approval for the engineering work of the Mambilla Hydro Electric Power Plant in Taraba State at a sum of $\$ 5.792 \mathrm{bn}$. The project includes the construction of four dams, one of which would be 150 metres high; two others would be 70 metres high while the smallest dam will be 50 metres in height. 
The second aspect is cost of land; an industry is always tried to be installed in outer city area, as the people are less so it is easy to get pollution board approval and reasonable cost of land. Other factors to consider in the location include Natural routes, Transportation, Market, Labour etc.

\subsection{LITERATURE REVIEW}

\subsection{Theoretical Framework}

Industry is an economic activity concerned with the processing of raw materials and manufacture of goods in factories and the services, which surround the use of these goods. The term industry covers a multitude of meanings; in its narrowest sense, it may only refer to manufacturing- the making of goods but in its broadest sense, it refers to all stages and types of economic activity including extraction, construction and services.

Location of an industry is the idea and practice of establishing an industry by either government or an entrepreneur in a given area for economic, geographical, social or political reasons. Industrial location can also be defined strategic placement of various economic activities in relation to some specific factors. Perfect location of industry depends on factors like land, labour, capital, transportation, etc.

\section{$2.2 \quad$ Types of Industry}

$>$ Primary industry: Is any activity in which natural resources are acquire from the earth surface. Examples of primary industry include agriculture, fishing, dairy farming, forestry, mining, and quarrying.

$>$ Secondary industry: Deals with the manufacture of finished products by changing its shape or real nature and adding utility to it; resources collected at the primary level are changed into other products, thereby involving a certain amount of manufacturing. Examples of secondary industry include making sugar from sugarcane, converting of iron ore to steel etc.

$>$ Tertiary industry-Tertiary industry may be summarized as the distributive trades and as such, it includes the commercial services such as transport, wholesaling and retailing.

$>$ Service industry/Quaternary industry- quaternary industry comprises of all personal services. Unlike tertiary industry, it does not deal with goods but with people and requires generally higher levels of skill, expertise and specialization. Activities in such fields such as education, research, administration and financial management may be termed quaternary.

\subsection{Theories of Location of Industry}

When attempting to predict where a business should be located we should take into consideration three (3) assumptions; business owners want to maximise their advantages over 
competitors, they want to maximise their profit and they take into account variable cost such as energy supply, transport cost, labour cost etc. Thus, in doing so we shall come across theories Weber's least cost theory, Losch's Profit maximisation theory and Locational independence theory.

Weber's least cost theory: Alfred Weber formulated a theory of industrial location in which an industry is located where the transportation costs of raw materials and final product is a minimum. He singled out two special cases. In one, the weight of the final product is less than the weight of the raw material going into making the product. Weber's model seeks to design a least cost industrial location sighting three (3) basic economic factors; Transportation cost, Labour cost and Agglomeration economies.
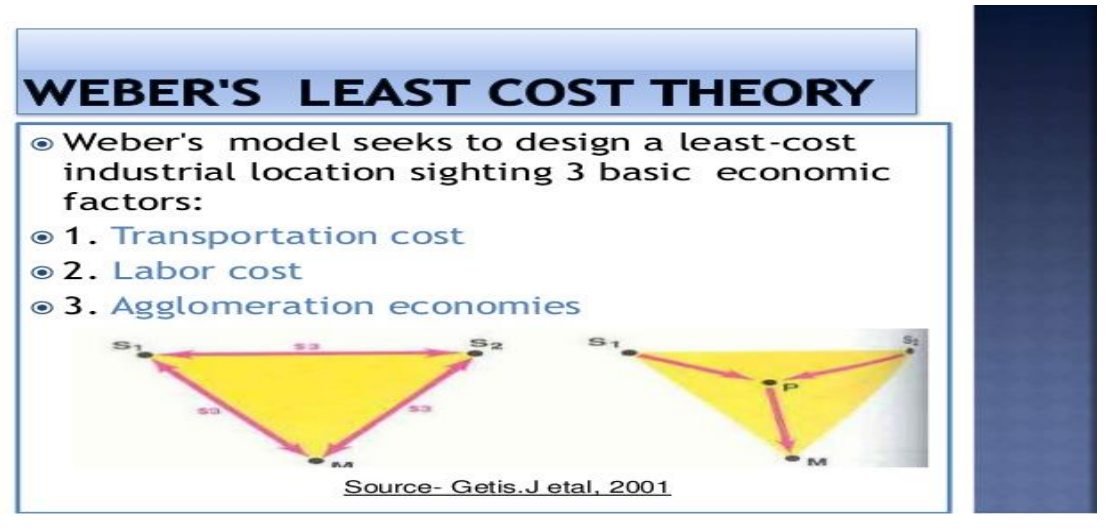

August Losch, a German economist, published his theory of 'Profit Maximisation' in the year 1954. The least cost location theory of Weber was wholly discarded by Losch. In fact, he suggested that, 'profit maximization' is the only objective of the entrepreneur, whether it is state or an individual. The theory states that the correct location of an industry lies where its profit is greatest.

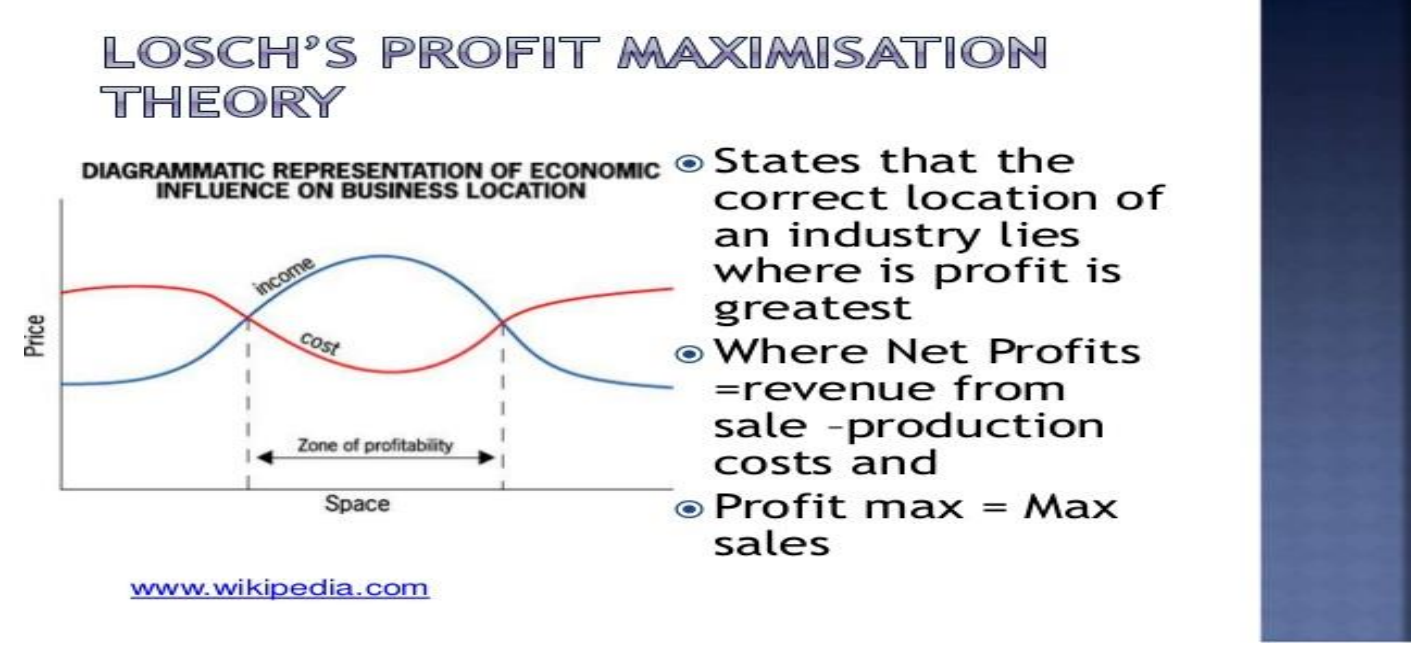

\subsection{Location of Industry Factors}


There are two types of approaches to industrial location; one is regional, attempts to assess the reasons why certain locations are attractive to industrialization generally and the second approach is industrial in perspective, and seeks to explain why an individual industry or firms are attracted to a particular location.

\section{FACTORS WHICH INFLUENCE mNDUSTRRAL LOCATION}
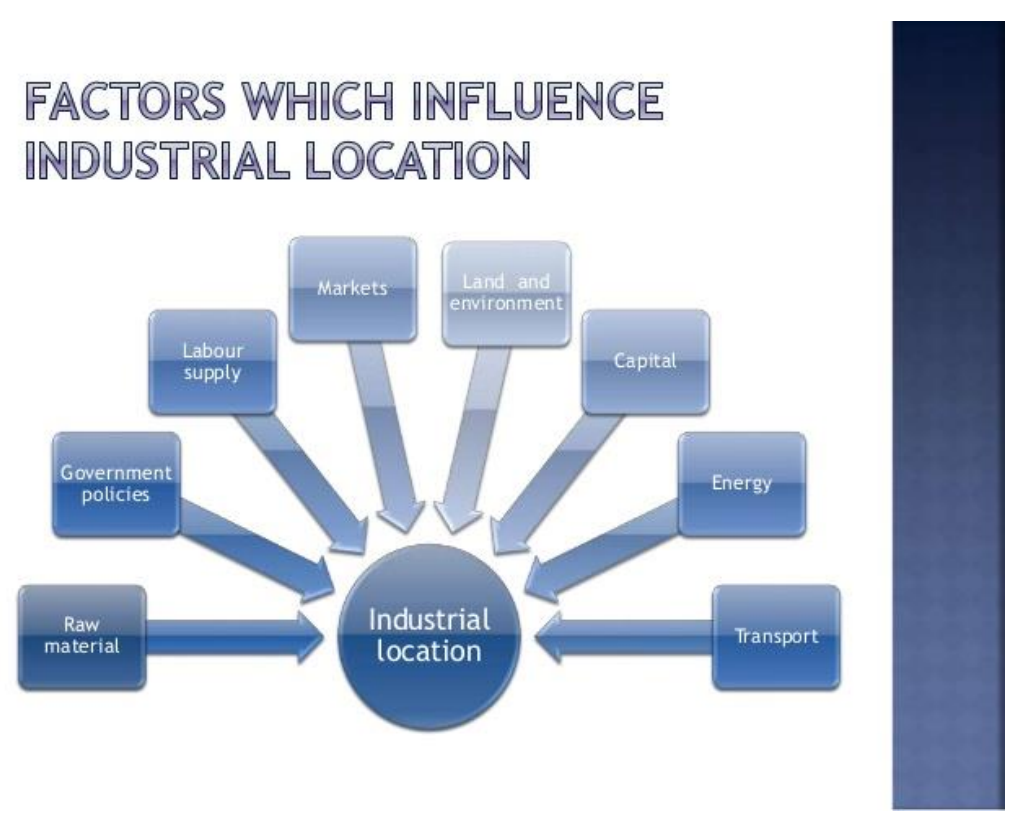

\section{Figure one - Location of Industry Factors}

The factors to be considered are many into the following below:

1) Human and Economic

$>$ Labour: A large cheap labour force is required for labour-intensive manufacturing industries but High-tech industries have to locate where suitable skilled workers are available. Estall and Buchanan showed in 1961 that labour costs can vary between 62\% in clothing and related industries to $29 \%$ in the chemical industry; in the fabricated metal products industries they work out at $43 \%$.

> Market: An accessible place to sell the products is essential for many industries: for bulky, perishable, fragile, size and prestige.

Dransport: A good transport network helps reduce costs and make the movement of materials easier.

Cost of land: Sites in rural areas are usually cheaper than urban area.

$>$ Capital: Amount of money needed to start the business.

$>$ Government policies and politics: Industrial development is encouraged in some areas and restricted in others. This days Government intervene for various social, political and strategic reasons; For instance, USSR industries have been moved eastward into the Urals, Tashkent and Ukraine. 
Water: Many industries are established near rivers, canals and lakes. Iron and steel industry, textile industries and chemical industries require large quantities of water, for their proper functioning.

$>$ Climate: Areas with hash climate are not good for industries because people tend to work only where living conditions are favourable.

$>$ Others: Banking facilities, Efficient Organisation, Industrial agglomeration, Industrial Inertia and Insurance.

2) Physical

$>$ Raw materials: The factory needs to be close to raw material.

$>$ Energy supply: Regular supply of power is a pre-requisite for the localisation of industries. Coal, mineral oil and hydro-electricity are the three important conventional sources of power. Most of the industries tend to concentrate at the source of power.

$>$ Natural routes: River valleys and flat areas were essential in the days before railways and motorways made the movement of materials easier.

$>$ Site and land: Most industries require large accessible areas of cheap, flat land on which to build their factories.

\subsection{CONCLUSION}

Location of industry is the geographical spread of economic activity within an economy. A multitude of factors influence the location decisions of firms and industries like proximity to raw materials, water, labour, market, power etc. It should be noted that business owners want to maximise their advantages over competitors so in locating an industry they want to maximise their profit and they take into account variable cost such as energy supply, transport cost, labour cost etc.

\section{References}

1. Barcelona Field Sudies Center; Location of Industry Factors

2. Defoaming: Theory and Industrial Applications 1993

3. Economic theory of the industry Book by Michael Waterson 1984

4. Factors Influencing the Location of Industries: Geographical and Non Geographical Factors Article shared by Smriti Chand

5. Industrial Location Geo 2101 Carlesa Duncan 12/0613/0712

6. Industrial Organization: Markets and Strategies Textbook by Martin Peitz and Paul Belleflamme 2010

7. Industrial Organization: Theory and Applications Book by Oz Shy 1998

8. Industrial Organization: Theory and Practice Book by Don E. Waldman and Elizabeth J. Jensen 1998

9. Industry from Wikipedia, the Free Encyclopedia

10. Industry: Definition, Types of Industries and Factors of industrial Location by JotScroll

11. The Punch; FG Awards \$5.8bn Mambilla Power Plant Contract Published August 2017

12. The Theory of Industrial Organization Book by Jean Tirole 1988

13. Theory of the location of industries Book by Alfred Weber 1909 